fracture ; delicate banding is apparent though the lenticular and irregular nature of this banding suggests plasticity at some stage in its formation ; specimens often disintegrate in the presence of water. In thin section the banded character is clearly seen ; in a groundmass probably composed of kaolinite, abundant roundish aggregates occur in which vermicular rouleaux of kaolinite are conspicuous ; solitary rouleaux of kaolinite also occur. Micro-organisms from this tonstein horizon at Hilton Main Colliery have been figured by Moore (1964A, Pl. 1, figs. 4, 5).

In the Forest of Wyre (Shropshire) Coalfield, a particularly interesting example has been found at Highley Colliery where a mottled red, green, and grey tonstein occurs in red beds of Etruria Marl facies, at a position 95 feet above the correlative of the Charles (Aegir) Marine Band. It is tempting to equate this tonstein horizon with that described above from the Cannock Chase Coalfield, but the southward facies change from grey Coal Measures to the Etruria Marl type of sedimentation presents additional difficulties to detailed correlation with South Staffordshire by conventional means, and in view of the doubts raised in this letter about the stratigraphical utility of tonsteins, and the relatively high incidence of their occurrence revealed by Salter, it would be wrong to rely too heavily on the correlation value of the tonstein itself.

The possibility that tonsteins have some connection with facies changes of dirt bands in coals and with seam splitting is interesting, and Salter's investigation of dirt bands in coal seams may throw some light on this. Our investigation of the stratigraphical utility of several other tonstein horizons in the West Midlands coalfields will continue in the hope that it makes some contribution to the solution of problems associated with tonsteins and their definition.

\title{
REFERENCES
}

EARP, J. R., 1961. Exploratory boreholes in the North Staffordshire Coalfield. Bull Geol. Surv. G.B., 17, 153-190.

MoORe, L. R., 1964. The Microbiology, Mineralogy, and Genesis of a Tonstein. Proc. Yorks. Geol. Soc., 34, 235-291.

1964A. The Microbiology of some Tonsteins. C.R. V' Congr. Strat. et. Géol. Carbonif., Paris, 1963, 587-592.

SCHEERE, J., 1955. Contribution à l'étude des Tonstein du Terrain houiller belge. Publ. Ass. Etud. Paléont., 19, 1-38.

1958. La pétrologie des tonstein du Houiller belge. Bull. Soc. Belge. Géol. Pal. Hydr., 66, 300-317.

N.C.B., West Midlandos Division,

R. H. HoARE.
HimLeY HaLl,
DUDLEY,
Worcs.

21st June, 1965.

\section{SILURO-DEVONIAN BOUNDARY}

SIR,-It is good to see that at long last a prominent member of the Ludlow Research Group has, albeit somewhat reluctantly, retracted one of the major tenets of the Group's creed. Previously they had all adhered rigidly to the belief that the Ludlow Bone Bed marked the base of the Devonian System. Now it is evident that Dr. Holland (1965) has been convinced by the case presented by Dr. H. Jaeger of Berlin on the graptolites $(1964,1965)$ and by myself on the vertebrates (Tarlo, 1964, 1965), that the Siluro-Devonian boundary should be placed at the base of the Monograptus uniformis Zone, which appears to coincide with the base of the Dittonian (sensu Allen and Tarlo, 1963). This represents a compromise between two extreme views, on the one hand that of the Ludlow Research Group, and on the other that of several workers on the Continent who wish to extend the range of the Silurian to include all the graptolites, even though some of them are now known to occur as high as the Siegenian. General acceptance of Dr. Jaeger's proposal 
for the Siluro-Devonian boundary will be of considerable value, since it will facilitate direct correlations between rocks of this age in Britain and those in Central Europe. In fact it has already received support from various quarters both here and abroad, and it is to be hoped that the remaining members of the Ludlow Research Group will now be persuaded to follow Dr. Holland's courageous stand.

Once this is achieved, the only serious problem remaining is how to name the beds above those of the British Ludlovian Stage, now brought within the Silurian. Dr. Jaeger tends to favour the retention of the name Downtonian for them, but since the change was due in large measure to the unsatisfactory nature of the Ludlow Bone Bed for correlating with the Continental sequence, using his name would still leave us with the same problem. For this reason I have suggested that it might be preferable to extend the Ludlovian to include the beds in question, as there seems little justification for interpolating an entirely new Stage between the marine Ludlovian and the Gedinnian. In any event there is a historical precedent for including the re-defined Downtonian in the Ludlovian, for Murchison originally included the Ludlow Bone Bed, the Downton Castle Sandstone, and the Tilestone Formation within his Upper Ludlow Rock.

\section{REFERENCES}

Holland, C. H., 1965. The Siluro-Devonian Boundary. Geol. Mag., 102, 213-22i.

JAEGER, H., 1964. Beiträge zur regionalen Geologie Thüringens und angrenzender Gegiete sowie zu anderen Problemen. Abh. deutsch. Akad. Wiss. Berlin, 1964, 27-51.

1965. Referate. Symposium-Band der 2. Internationalen Arbeitstagung uber die Silur/Devon-Grenze. Geologie. Berlin, 14, 348-364.

TARlo, L. B. H., 1964. Psammosteiformes (Agnatha)-a review with descriptions of new material from the Lower Devonian of Poland. 1. General Part. Palaeont. polon., 13, 1-135.

1965. Discussion in Dineley, D. L., Demonstration : Ostracoderms from the Siluro-Devonian of Somerset Island, Arctic Canada. Proc. Geol. Soc. Lond., 1624, 98.

Department of Geology,

L. B. Halstead Tarlo.

UNIVERSITY OF READING.

31 st July, 1965 .

\section{K-A STUDIES IN SCOTLAND}

SiR,--Our paper in the March-April issue of this magazine included in Table 3 ages for specimens of Dalradian schists from near Loch Fyne (localities numbered 45 to 50 ). We wish to record that all these specimens were from the vicinity of Sithean Sluaigh and their grid references are as follows :-

$\begin{array}{cc}\text { Locality } & \text { No. } \\ 45 & \text {. } \\ 46 & : \\ 47 & : \\ 48 & : \\ 49 & : \\ 50 & \text {. }\end{array}$

Grid Reference.

NS 072981

NS 067978

NS 067980

NS 073979

NS 073979

NS 067980

In addition, there is an omission in the grid reference of locality 72 which should read NN 590930 and a mis-spelling in locality No. 93 which should read 'S Airde Beinn.
Department of Geodesy and
J. A. Miller.
Geophysics, CAMBRIDGE.
DEPARTMENT OF GeOLOGY,
P. E. Brown.

SHEFFIELD.

12th July, 1965. 